\title{
STUDY OF PROTEINS IN THE LARVAE OF AEDES AEGYPTI AND ANOPHELES STEPHENSI AFTER EXPOSURE TO THE PHYTOTOXIN LASIOSIPHON ERIOCEPHALUS
}

\author{
R.G. Patil \\ Emeritus Fellow, P.G. Department of Zoology, \\ L.B.S.College of Arts, Science and Commerce, Satara \\ Email ramraopati121@yahoo.com
}

Communicated : 15.12 .18

Accepted : 15.01.19

Published: 30.01 .19

\begin{abstract}
Protein is an important and essential organic constituent which plays important role in the cellular metabolism. Mosquito Aedes aegypti and Anopheles stephensi is a vector for transmission of diseases like malaria, dengue and yellow fever. Mosquitoes are controlled by synthetic chemicals but scientists are in the search of effective alternative. In this study phytotoxin Lasiosiphon eriocephalus is studied for their effects on the proteins in the larvae of mosquitoes $A$. aegypti and A. stephensi. These larvae of mosquitoes are exposed to the phytotoxin Lasiosiphon eriocephalus for $2,4,8,12,24$ and $48 \mathrm{hrs}$. It is observed that proteins are decreased in the exposed larvae of $A$. aegypti and $A$. stephensi. The proteins are found to be decreased with increase in time.
\end{abstract}

Key words :- A. aegypti, A. stephensi, phytotoxin and Lasiosiphon eriocephalus

\section{INTRODUCTION:}

Mosquitoes spread all over the world except Antartica. Mosquito species are more active in warm and humid tropical regions. Mosquitoes had created health problem all over the world. There are different diseases caused by biting of mosquitoes. Actually mosquitoes act as a vector for transmitting diseases causing viruses and parasites. Among the mosquitoes like A. aegypti and $A$. stephensi act as a vector for transmitting several diseases like dengue, malaria, chicken guinea and yellow fever.

Use of synthetic chemicals had resulted in the production of resistant mosquitoes which are spread all over the world (Chevillon et al., 1999). Because of high cost of chemicals, concern to the environment, effect on non target population and resistance in mosquito the use of synthetic chemicals had been minimized (Brown, 1986, Russell et al., 2009). Use of phytotoxins in the control of mosquitoes is used as new alternative for the synthetic chemicals. The efforts have been made in this work to study the effects on phytotoxin $L$. eriocephalus on the proteins of larvae of mosquito A. aegypti and A. stephensi.

\section{MATERIAL AND METHODS :-}

Larvae of Aedes aegypti and Anopheles stephensi with development of 5 days and phytotoxin Lasiosiphon eriocephalus were selected for this study. These larvae of $A$. aegypti and $A$. stephensi were exposed for $2,4,8,12,24$ and 48 hrs. respectively to conc. 213.07 and $210.14 \mathrm{ppm}$ of phytotoxin L. eriocephalus. These concentrations 213.07 and 210.14 ppm are the LC $_{50}$ values of phytotoxin $L$. eriocephalus respectively for the $A$. aegypti and $A$. stephensi.

The alcoholic extracts of powder of leaves of L. eriocephalus had been prepared with the help of Soxhlet's apparatus and Lowry's method (1951) was used to study the proteins in the larvae.

\section{OBSERVATION:}

Table No.1. Effects on proteins of mosquito larvae $A$. aegypti after exposure to the phytotoxin L. eriocephalus

\begin{tabular}{|c|l|l|l|}
\hline $\begin{array}{c}\text { Exposure } \\
\text { Period } \\
\text { (hrs) }\end{array}$ & \multicolumn{2}{|c|}{ Proteins } & $\begin{array}{c}\text { Percentage } \\
\text { decrease in } \\
\text { mg/gm of body wt.) }\end{array}$ \\
\cline { 2 - 4 } & Normal & Exposed & \\
\hline 2 & 27.50 & 27.05 & 1.63 \\
\hline 4 & 24.50 & 23.90 & 2.44 \\
\hline 8 & 26.00 & 25.30 & 2.69 \\
\hline 12 & 29.50 & 28.60 & 2.37 \\
\hline 24 & 28.00 & 27.10 & 3.21 \\
\hline
\end{tabular}




\begin{tabular}{|l|l|l|l|}
\hline 48 & 26.50 & 25.30 & 4.52 \\
\hline
\end{tabular}

Table No.2. Effects on proteins of mosquito larvae A. stephensi after exposure to the phytotoxin L. eriocephalus

\begin{tabular}{|c|c|c|c|}
\hline \multirow{2}{*}{$\begin{array}{c}\text { Exposure } \\
\text { Period } \\
\text { (hrs) }\end{array}$} & \multicolumn{2}{|c|}{$\begin{array}{c}\text { Proteins } \\
\text { (mg/gm of body wt.) }\end{array}$} & \multirow[t]{2}{*}{$\begin{array}{l}\text { Percentage } \\
\text { decrease in } \\
\text { proteins (\%) }\end{array}$} \\
\hline & Normal & Exposed & \\
\hline 2 & 23.20 & 22.60 & 2.58 \\
\hline 4 & 24.50 & 23.90 & 2.44 \\
\hline 8 & 28.50 & 27.70 & 2.80 \\
\hline 12 & 26.50 & 25.60 & 3.39 \\
\hline 24 & 24.00 & 23.00 & 4.16 \\
\hline 48 & 24.90 & 23.80 & 4.41 \\
\hline
\end{tabular}

Fig. No. 1. Effects on proteins of mosquito larvae A. aegypti after exposure to the phytotoxin $L$. eriocepha

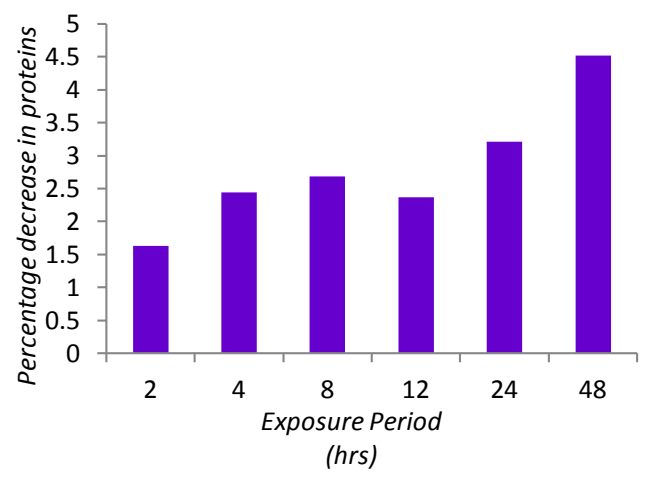

lus

Fig. No. 2. Effects on proteins of mosquito larvae A. stephensi after exposure to the phytotoxin $L$. eriocephalus

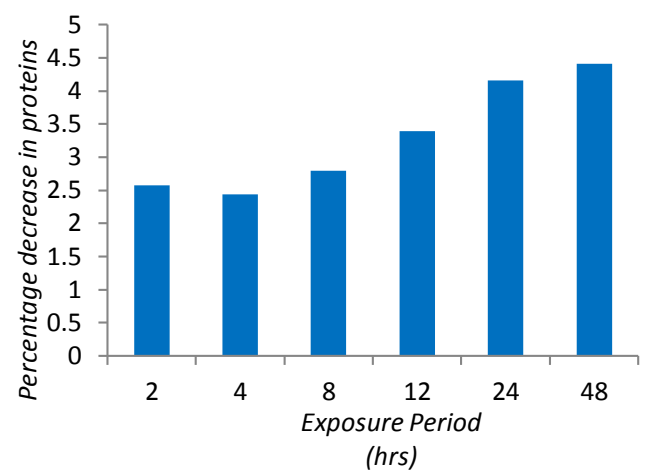

When larvae of $A$. stephensi exposed for 2, 4, $8,12,24$ and 48 hrs.of phytotoxin L. eriocephalus the proteins were found decreased with increase in exposure period. The percentage decrease in proteins is observed as $2.58 \%, 2.44 \%, 2.80 \%$, $3.39 \%, 4.16 \%$ and $4.41 \%$ respectively to the exposure period 2, 4, 8, 12, 24 and $48 \mathrm{hrs}$.

\section{DISCUSSION :}

Protein is a energy source used during stress condition of animals. When larvae of $A$. aegypti and $A$. stephensi exposed to the phytotoxin from L. eriocephalus the protein contents in the both larvae get depleted. The proteins in the larvae of A. aegypti get decreased by $1.63 \%, 2.44 \%, 2.69 \%$, $2.37 \%, \quad 3.21 \%$ and $4.52 \%$ respectively for exposure periods $2,4,8,12,24$ and $48 \mathrm{hrs}$. whereas proteins in the larvae $A$. stephensi get decreased by $2.58 \%, 2.44 \%, 2.80 \%, 3.39 \%$, $4.16 \%$ and $4.41 \%$ respectively for exposure period $2,4,8,12,24$ and 48 hrs.

Similar types of results were obtained by Sharma et al. (2006) in Culex quinquafasciatus and Anopheles due to the effect of A. annua. Annadurai and Rembold (1993) and Li XD et al. (1995) had observed decreased protein level in Spodoptera litura and Schistocera gregaria.

According to Sharma et al. (2006) decrease in proteins is due to the interference of phytotoxin in the protein synthesis and also due to the degeneration and rupturing of larval tissue. Umminger (1970) was of the opinion that protein is a energy source to spare during stress condition.

In our study larvae of $A$. aegypti and $A$. stephensi when exposed to the phytotoxin $L$. eriocephalus, may interferes protein synthesis in the larvae which causes depletion in the protein amount. Furthermore due to the stress condition larvae used the protein source for energy which may also results in the depletion in proteins. 
Therefore from above discussion it is concluded that when larvae exposed to the phytotoxin $L$. eriocephalus it interferes protein synthesis and also stress condition is produced which further results in the depletion of proteins. It is also concluded that decrease in proteins is correlated with increase in exposure period.

\section{ACKNOWLEDGEMENT :-}

I am vary much thankful to UGC for awarding me the 'Emeritus Fellowship'. I am also thankful to the Prin. Abhayakumar Salunkhe, President of Shri Swami Vivekanand Shikshan Sanstha, Kolhapur and Prin. Dr. R. V. Shejwal, Lal Bahadur Shastri college of Arts, Science and Commerce, Satara, for providing facilities for the research and for continuous encouragement.

\section{REFERENCES:-}

Annadurai RS, Rembold H.( 1993) : Azadirachtin A modulates the tissue specific 2D polypeptides patterns of the dessert locust, Schistocercia gregaria. Naturwissenschaften; 80: 127-130.

Brown A.w. (1986) : Insecticide resistance in mosquitoes :a a pragmatic review J. Am Mosquito Control Association, 2, 123-140.

Chevillon, Christine, Raymond, Michell, Guillemaud Thomas, Pasteur and Nichol (1999) : Population genetics of insecticide resistance in the mosquito Culex pipiens.Biol.J.Linn.Soc., (1-2), 147-157.

Li XD, Chen WK, Hu MY. (1995): Studies on the effects and mechanism of azadirachtin and rhodojaponin on Spodoptera litura (F.). J South China Agricultural University; 16: 80-85.

Lowry, O.H., Rosebrough, N.J., A.L. and Randall R.J. (1951): Protein measurement with folin phenol reagent., J.Biol.Chem., 193; 265275.
Russell TL, Kay BH, Skilleter GA (2009) : Environmental effects of mosquito insecticides on saltmarsh invertebrate fauna. Aquat. Biol., 6, 7790.

Sharma P, Mohan L, Srivastava CN. (2006) :Growth inhibitory nature of Artemisia annua extract against Culex quinquefasciatus Say. J Asia Pacific Entomol; 9: 389-395.

Sharma P, Mohan L, Srivastava CN. (2006) : Phytoextract-induced developmental deformities in malaria vector. Bioresour Technol b; 97: 15991604.

Sharma P, Mohan L, Srivastava CN. (2006) : Phytoextract-induced developmental deformities in malaria vector. Bioresour Technol 97: 15991604.

Sharma P, Mohan L, Srivastava CN. (2006) : Growth inhibitory nature of Artemisia annua extract against Culex quinquefasciatus Say. J Asia Pacific Entomol 9: 389-395.

Umminger, B.L. (1970) : Physiological studies in super cooled hill fish Fundulus heteroclitus, III Carbohydrate metabolism and survival at sub zero temperature, J.Exp.Zool., 173, 159-174. 